Journal of the

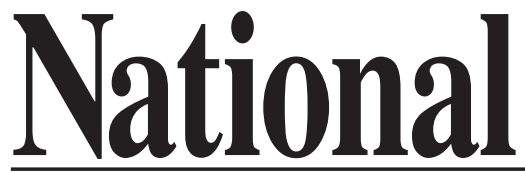

Academy or

Forensic
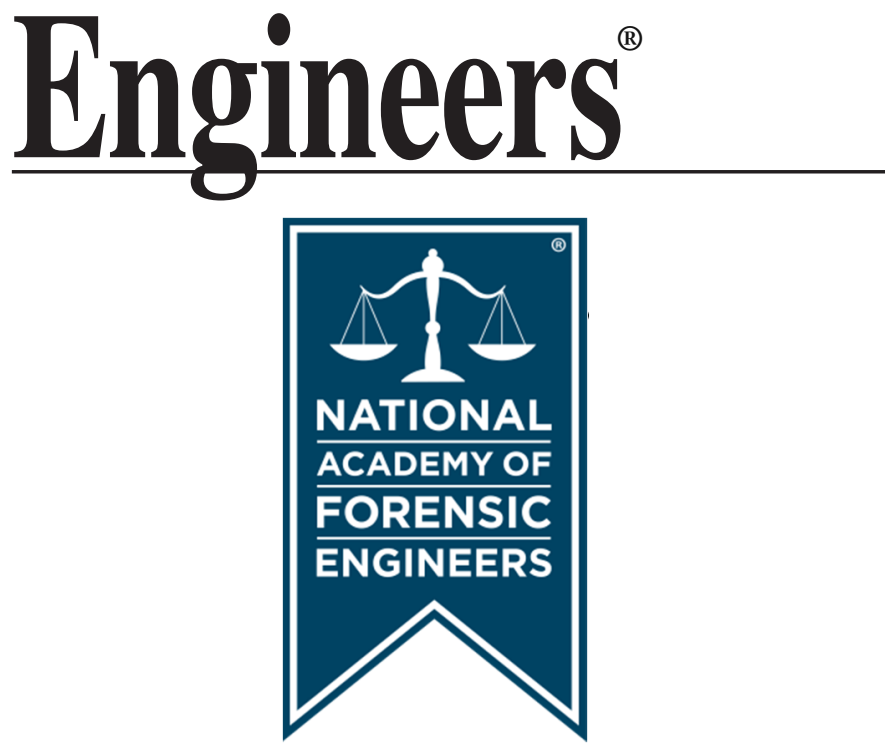

http://www.nafe.org ISSN: 2379-3252 


\section{Forensic Engineer Investigation of 2005 US Gulf Coast Hurricane Damages}

by William C. Bracken, P.E. (605S)

\section{Introduction}

During the summer and fall of 2005 the US Gulf Coast once again saw damage from an onslaught of hurricanes, category 2 and stronger. In all a total of four hurricanes impacted the US Gulf Coast from southern Texas to the southeastern coast of Florida. Each storm exhibited very different characteristics with distinct modes of damage and resulting structural failures. This paper presents a summary of the damage and resulting modes of structural failure result ing from each storm. This summary was made and compiled by this author who functioned as the State of Florida's lead Structures Specialist during the 2005 storm season. This summary was based on immediate post-event reconnaissance as well as subsequent in-depth professional investigations.

\section{Basis of Summary}

As a FEMA trained Structures Specialist (StS), this author, as he did in 2004, once again was able to provide engineering expertise to the urban search and rescue efforts performed by Florida in response to the 2005 US Gulf Cost hurricanes. As the lead StS, the author was tasked with initial post-storm reconnaissance, assisting with the deployment of state and federal resources, the coordination of ground search operations and the presentation of findings to local, state and federal ground coordination officials.

This summary is based on immediate post-event surveys of the affected areas both from the ground and air. These surveys afforded the opportunity to make note of the various types and extent of damages wrought by each storm. This summary is also based on the subsequent post-event assessments that were based on in-depth FE investigations.

\section{Hurricane Dennis}

Hurricane Dennis made land fall in the panhandle of Florida in the Navarre Beach area on July 10, 2005. The maximum sustained wind speed at landfall was recorded at $100 \mathrm{mph}$ with gusts in excess of $110 \mathrm{mph}$. Although this hurricane was listed as a category 2 storm, its forward speed of nearly 20 miles per hour combined with its last minute rapid deterioration substantially reduced 
Copyright @ National Academy of Forensic Engineers (NAFE) http://www.nafe.org. Redistribution or resale is illegal. Originally published in the Journal of the NAFE volume indicated on the cover page. ISSN: 2379-3252

storm surge damage. This storm delivered limited wind pressure damage and only sporadic tornado damage within the eastern portion of the Florida panhandle. The damage resulting from this storm was concentrated along the coast and included missing and damaged roofs, blown down trees, blown down power poles, damage and partial collapses of previously damaged structures. It was noted that the landfall of Dennis was approxi-

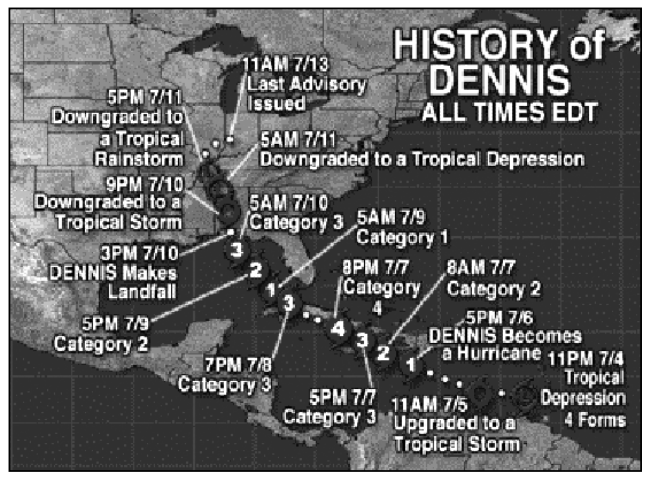

Figure 1

History of Hurricane Dennis mately 40 miles east of the point of landfall for Hurricane Ivan, (a category 3 storm of the previous year). It was also noted that while the Navarre Beach barrier island's structures were severely impacted, the storm caused little to no sub stantial damage in the Pensacola area immediately to the west. After landfall, the storm traveled north and was quickly reduced to a tropical storm.

\section{Hurricane Katrina}

Hurricane Katrina made land fall first on August 25, 2005 on the southeast coast of the state of Florida, then the southeast portion of Louisiana near the Louisiana Mississippi boarder on August 29, 2005. Katrina's Landfall on the Louisiana and Mississippi areas has been called the most costly storm in US history.

Hurricane Katrina's landfall on the southeast coast of Florida was recorded as a Category 1 with sustained winds between 80 and 90 miles per hour. Its forward speed of more than 15 miles per hour generated a neg-

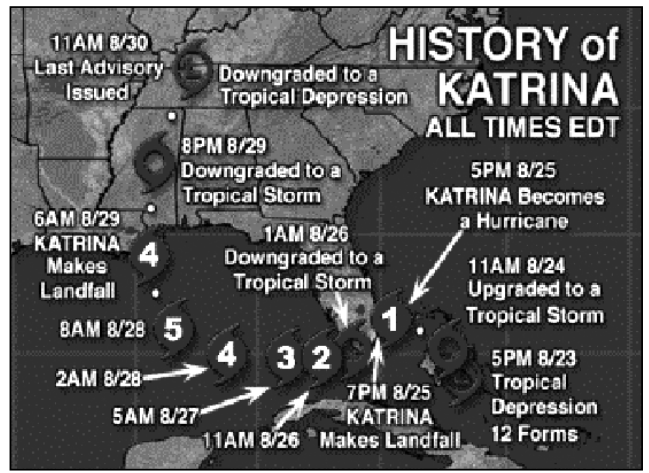

Figure 2

History of Hurricane Katrina ligible storm surge. The storm surge damage was manifest as moderate flooding 1-3 feet along with modest beach scour, moderate wind pressure damage and sporadic tornado damage.

Hurricane Katrina's landfall on the Louisiana and Mississippi areas was recorded as a Category 4 Hurricane with a storm surge of $20-30$ feet and sus 
Copyright @ National Academy of Forensic Engineers (NAFE) http://www.nafe.org. Redistribution or resale is illegal. Originally published in the Journal of the NAFE volume indicated on the cover page. ISSN: 2379-3252

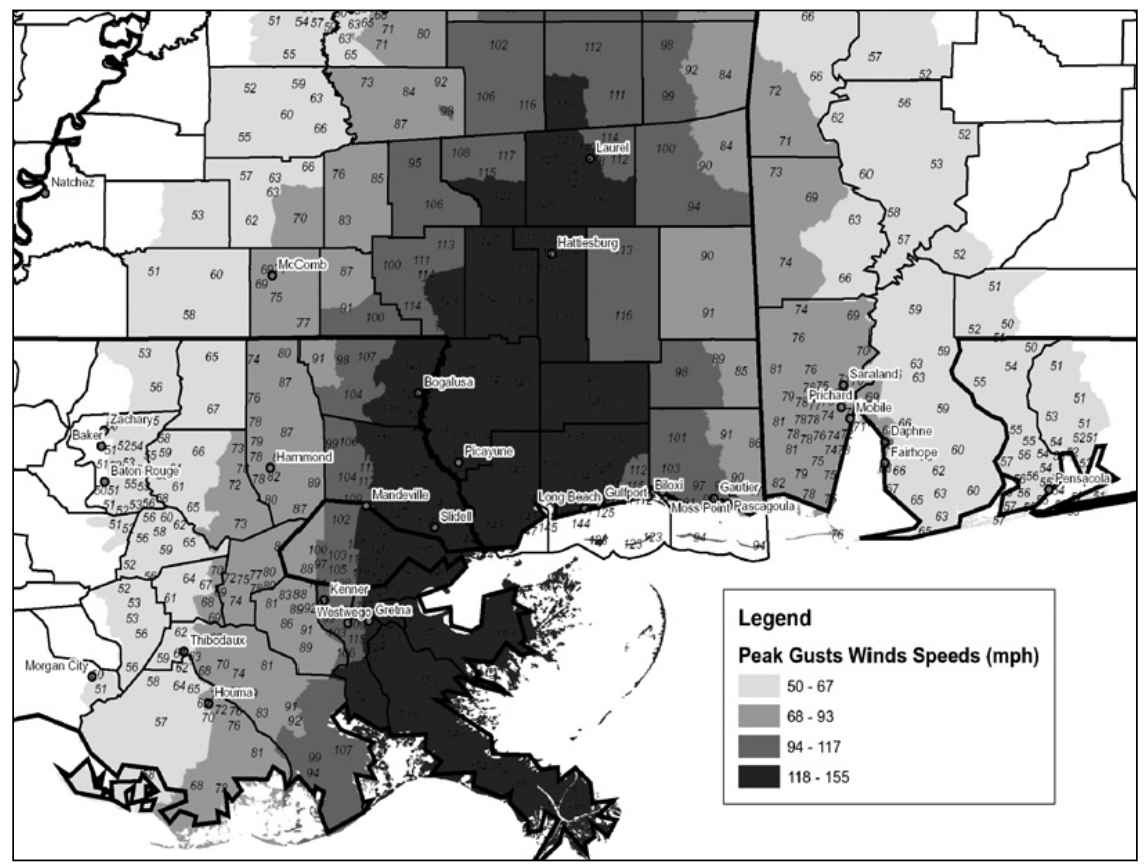

Figure 3

Peak Wind Gusts during Hurricane Katrina

tained winds of over 150 miles per hour. Its forward speed of approximately 8-10 miles per hour produced optimum conditions resulting in a record storm surge. This storm included severe wind pressure damage and severe tornado damage. The damage resulting from this storm included decimated coastlines, significantly damaged and/or destroyed structures, missing and damaged roofs, blown down trees, destruction of the basic infrastructure, partial collapses of older inland structures and total destruction of mobile homes.

The recorded storm surge and water depths within the coastal portions of Mississippi were estimated at 25 to 30 feet on the coast and up to 20 feet inland. This surge was much higher than that predicted by the Saffir-Simpson Scale and well above the levels recorded during Hurricane Camille of 1969. The surge resulting from this storm

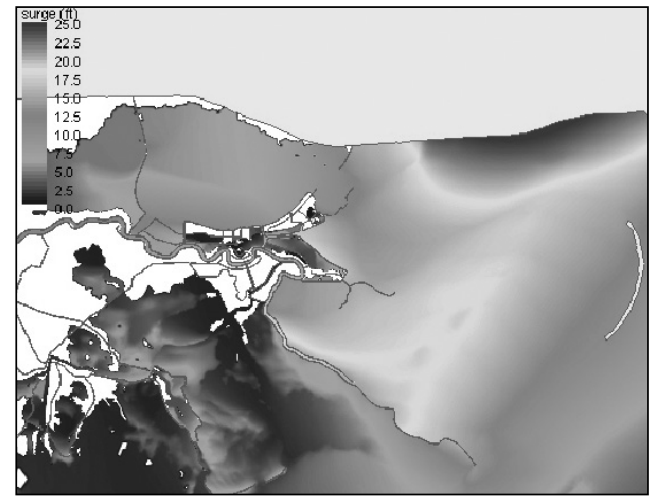

Figure 4

Estimated Storm Surges in southeast Louisiana 
Copyright @ National Academy of Forensic Engineers (NAFE) http://www.nafe.org. Redistribution or resale is illegal. Originally published in the Journal of the NAFE volume indicated on the cover page. ISSN: 2379-3252

also served to overtop and breach large portions of the levee system within the city and parishes to the south and east of New Orleans. Approximately $75 \%$ of the metropolitan New Orleans area was flooded as a result of these levee breaches. Breaches of the levee system occurred through two separate mechanisms, failure of the wall itself and overtopping of the wall.

\section{Hurricane Rita}

Hurricane Rita made land fall along the Texas Louisiana boarder on September 24, 2004. Its point of landfall was approximately 250 miles west of the Hurricane Katrinas landfall. The maximum sustained wind speed at landfall was recorded at 115 mph with gusts in excess of 130 $\mathrm{mph}$. Although this hurricane reached category 5 strength in the Gulf it came ashore as a weak category 3 storm. Its forward speed combined with its

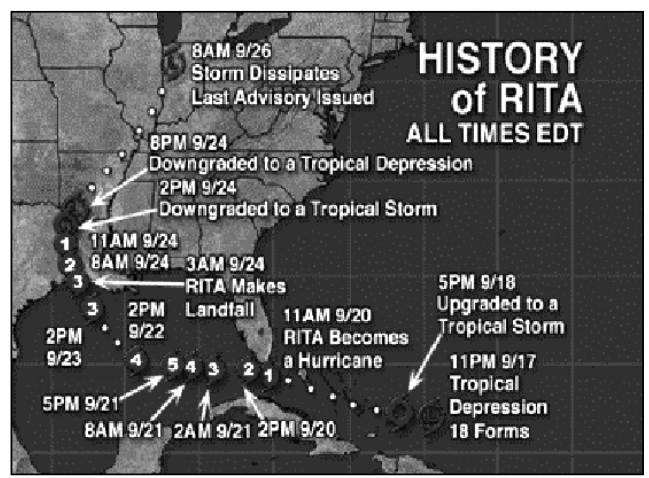

Figure 5

History of Hurricane Rita rapid deterioration reduced storm surge damage. This storm delivered limited wind pressure damage and only sporadic tornado damage within the western portion of Louisiana. The damage resulting from this storm was concentrated along the coast and included missing and damaged structures along the coastline, blown down trees, blown down power poles, damage and partial collapses of previously damaged structures. This storm did however serve to aggravate flooding problems within the New Orleans area as well as to hinder search and recovery operations.

\section{Hurricane Wilma}

Hurricane Wilma made land fall on the southwest cost of Florida in the Glades City area on October 24, 2005. This storm made landfall as a weak category 2 storm with maximum sustained wind speed recorded less than $115 \mathrm{mph}$ and onshore gusts of less than $120 \mathrm{mph}$. Its forward speed of more than 20 miles per hour generated a negligible storm surge. This storm also

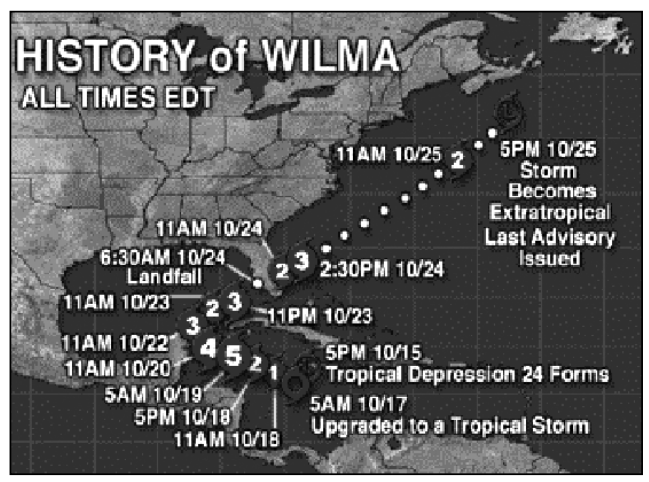

Figure 6

History of Hurricane Wilma 
Copyright @ National Academy of Forensic Engineers (NAFE) http://www.nafe.org. Redistribution or resale is illegal. Originally published in the Journal of the NAFE volume indicated on the cover page. ISSN: 2379-3252

NAFE 605S

GULF COAST HURRICANE DAMAGES

PAGE 127

exhibited moderate wind pressure damage and limited tornado damage. Noteworthy items included the fact that this storm traveled across the state through the unpopulated everglades and to the south of Lake Okeechobee. While traveling through the waters of the everglades the storm was reported to have strengthened. This storm then exited the state of Florida in the Palm Beach / Lauderdale area stronger than at time of landfall. Post-event assessments have found that the damage to the east coast was more pronounced than that observed and recorded on the west coast. It was also noted that portions of the wind field from this hurricane overlapped with the wind fields of three of the previous years hurricanes.

\section{Forensic Aspects of the 2005 Hurricane Season}

Litigiously contested issues arising from the 2005 hurricane season include; how to accurately differentiate 2005 damage from that of 2004, how to accurately assess the cumulative effects of hurricane damage on structures, and in the case of completely destroyed or washed away structures - how to properly segregate the extent of damage by respective mechanism. While this paper does not attempt to address such issues, it does provide the following table of data on wind strengths and anticipated damage based on the Saffir-Simpson Scale.

\begin{tabular}{|l|l|l|}
\hline $\begin{array}{c}\text { Saffir-Simpson } \\
\text { Scale }\end{array}$ & Wind Speed & \multicolumn{1}{|c|}{ Wind Damage } \\
\hline \hline S1 Hurricane & $74-95 \mathrm{mph}$ & $\begin{array}{l}\text { Damage primarily to unanchored mobile homes, shrubbery, and } \\
\text { trees. No significant damage to well anchored structures. Some } \\
\text { damage to poorly constructed signs. }\end{array}$ \\
\hline S2 Hurricane & $96-110 \mathrm{mph}$ & $\begin{array}{l}\text { Possible damage to roofing, windows and doors. Considerable } \\
\text { damage to shrubbery and trees with some trees uprooted. } \\
\text { Considerable damage to mobile homes, poorly constructed signs, } \\
\text { and piers. No major damage to secure structures. }\end{array}$ \\
\hline S3 Hurricane & $111-130 \mathrm{mph}$ & $\begin{array}{l}\text { Damage to shrubbery and trees with foliage blown off trees and } \\
\text { large trees blown down. Mobile homes and poorly constructed } \\
\text { signs are destroyed. Some damage to roofing and windows that } \\
\text { are unbraced. }\end{array}$ \\
\hline S4 Hurricane & $131-150 \mathrm{mph}$ & $\begin{array}{l}\text { Complete roof failures on smaller structures. Shrubs, trees, and all } \\
\text { signs are blown down. Complete destruction of mobile homes. } \\
\text { Extensive damage to doors and windows. }\end{array}$ \\
\hline S5 Hurricane & $>155 \mathrm{mph}$ & $\begin{array}{l}\text { Shrubs and trees blown down or uprooted. Considerable damage } \\
\text { to all roofs and signs extensive damage to windows and doors, as } \\
\text { well as complete failures of roofs on residences and industrial } \\
\text { structures. Extensive glass shattering and blown debris. } \\
\text { Complete destruction of all mobile homes and some smaller } \\
\text { structures. Smaller buildings are overturned or destroyed. }\end{array}$ \\
\hline
\end{tabular}

Figure 7

The Saffir-Simpson Scale with anticipated wind speeds and resulting wind damage 
Copyright @ National Academy of Forensic Engineers (NAFE) http://www.nafe.org. Redistribution or resale is illegal. Originally published in the Journal of the NAFE volume indicated on the cover page. ISSN: 2379-3252

This paper also provides the following table of data on surge strengths and anticipated damages. This table is also based on the Saffir-Simpson Scale.

\begin{tabular}{|c|c|c|}
\hline $\begin{array}{l}\text { Saffir-Simpson } \\
\text { Scale }\end{array}$ & Storm Surge & Water Damage \\
\hline S1 Hurricane & $\begin{array}{c}\text { Generally } \\
4-5 \mathrm{ft} \\
\text { above normal }\end{array}$ & $\begin{array}{l}\text { Low-lying coastal roads inundated, minor pier damage, some } \\
\text { small craft in exposed anchorage torn from moorings. }\end{array}$ \\
\hline S2 Hurricane & $\begin{array}{c}\text { Generally } \\
6 \text { - } 8 \text { feet } \\
\text { above normal }\end{array}$ & $\begin{array}{l}\text { Coastal roads and low-lying escape routes inland cut by rising } \\
\text { water } 2 \text { to } 4 \text { hours before arrival of hurricane center. Considerable } \\
\text { damage to piers. Marinas flooded. Small craft in unprotected } \\
\text { anchorages torn from moorings. Evacuation of some shoreline } \\
\text { residences and low-lying areas required. }\end{array}$ \\
\hline S3 Hurricane & $\begin{array}{c}\text { Generally } \\
9-12 \mathrm{ft} \text { above } \\
\text { normal }\end{array}$ & $\begin{array}{l}\text { Low-lying escape routes are cut by rising water } 3-5 \text { hours before } \\
\text { arrival of the hurricane center. Flooding near the coast destroys } \\
\text { smaller structures with larger structures damaged by battering of } \\
\text { floating debris. Terrain continuously lower than } 5 \mathrm{ft} \text { above mean } \\
\text { sea level may be flooded inland } 8 \text { miles }(13 \mathrm{~km}) \text { or more. } \\
\text { Evacuation of low-lying residences within several blocks of the } \\
\text { shoreline may be required. }\end{array}$ \\
\hline S4 Hurricane & $\begin{array}{c}\text { Generally } \\
13-18 \mathrm{ft} \\
\text { above normal }\end{array}$ & $\begin{array}{l}\text { Low-lying escape routes may be cut by rising water } 3-5 \text { hours } \\
\text { before arrival of the hurricane center. Major damage to lower } \\
\text { floors of structures near the shore. Terrain lower than } 10 \mathrm{ft} \text { above } \\
\text { sea level may be flooded requiring massive evacuation of } \\
\text { residential areas as far inland as } 6 \text { miles }(10 \mathrm{~km}) \text {. }\end{array}$ \\
\hline S5 Hurricane & $\begin{array}{c}\text { Generally } \\
>18 \mathrm{ft} \\
\text { above normal }\end{array}$ & $\begin{array}{l}\text { Low-lying escape routes are cut by rising water } 6-8 \text { hours before } \\
\text { arrival of the hurricane center. Major damage to lower floors of all } \\
\text { structures located less than } 15 \mathrm{ft} \text { above sea level and within } 750 \\
\text { yards of the shoreline. Massive evacuation of residential areas on } \\
\text { low ground within } 5-10 \text { miles ( } 8-16 \mathrm{~km} \text { ) of the shoreline may be } \\
\text { required requiring massive evacuation of residential areas as far } \\
\text { inland as } 15 \text { miles. }\end{array}$ \\
\hline
\end{tabular}

\section{Figure 7}

The Saffir-Simpson Scale with anticipated storm surges and resulting damage

\section{Summary}

Wind damage as well as water damage is unique and identifiable. However, when combined, segregating respective contributions by each mechanism is complicated and not easily executed. Specifically, one will serve as the initiating mechanism and the other will serve as a contributing mechanism. However, establishing the initiating mechanism is not necessarily germane given that the initiating mechanism is not necessarily the greatest contributor to the damage. In other words, wind can act as the initiating mechanism thereby weakening a structure and facilitating significant damage from flood. Conversely, if flood is the initiating mechanism it can weaken a structure and facilitate significant wind damage.

Therefore, it is the opinion of the author that the only means of precisely assigning a percent of contribution is to model pre-storm soil \& structural con ditions along with actual storm loading. Once modeled a comparison is then 
made to post-storm structural conditions. If the models findings correlate with the post storm conditions then a process of segregating out each separate loading can be performed and relative percentages assigned.

\section{References}

Accuweather.com, 2005. History of Hurricane Katrina. On the web at: www.hurricane.accuweather.com/hurricane/index.asp

American Society of Civil Engineers (ASCE), 2005. Preliminary Report on the Performance of the New Orleans Levee System in Hurricane Katrina on August 29, 2005. On the web at: www.asce.org/static/hurricane/orleans_report.cfm

Center for the Study of Public Health Impacts of Hurricanes, Louisiana State University. On the web at: www.hurricane.lsu.edu/floodprediction

Earth Scan Lab, Coastal Studies Institute, Louisiana State University. On the web at: www.esl.lsu.edu/home

Louisiana Geographic Information Center (LAGIC), 2005. 2005 Louisiana Hurricane Impact Atlas. On the web at: www.lagic.lsu.edue/hurricanes.htm

National Oceanic and Atmospheric Administration . On the Web at: www.ncddc.noaa.gov/Katrina

Ross, Kelley L., Ph.D., The Beaufort Wind Force Scale, The Saffir-Simpson Hurricane Scale, \& the Fujita Scale of Tornado Intensity. On the web at: www.friesian.com/wind.htm. 
Copyright @ National Academy of Forensic Engineers (NAFE) http://www.nafe.org. Redistribution or resale is illegal.

Originally published in the Journal of the NAFE volume indicated on the cover page. ISSN: 2379-3252

PAGE 130

JUNE 2006 